\title{
Stratigraphy and paleoenvironments of the early to middle Holocene Chipalamawamba Beds (Malawi Basin, Africa)
}

\author{
B. Van Bocxlaer ${ }^{1,2}$, W. Salenbien ${ }^{1}$, N. Praet $^{1}$, and J. Verniers ${ }^{1}$ \\ ${ }^{1}$ Research Unit Palaeontology, Department of Geology and Soil Science, Ghent University, Krijgslaan 281 (S8), 9000 Ghent, \\ Belgium \\ ${ }^{2}$ Department of Paleobiology, Department of Invertebrate Zoology, National Museum of Natural History, Smithsonian \\ Institution, 10th and Constitution NW, Washington, DC 20560, USA
}

Correspondence to: B. Van Bocxlaer (vanbocxlaerb@si.edu, bert.vanbocxlaer@ugent.be)

Received: 18 March 2012 - Published in Biogeosciences Discuss.: 21 May 2012

Revised: 29 September 2012 - Accepted: 4 October 2012 - Published: 14 November 2012

\begin{abstract}
We describe the Chipalamawamba Beds, early to middle Holocene deposits at the southern margin of longlived Lake Malawi. The beds are exposed because of downcutting of the upper Shire River. The Chipalamawamba sediments are medium to coarse, yellow to brown sands deposited in lenses varying in horizontal extent from a few meters to several hundreds of meters. Four units are recognized; the first three mainly contain lacustrine sediments deposited during lake high stands about 10.6-9.7 cal ka BP (Unit 1), 7.6-6.5 cal ka BP (Unit 2) and 5.9-5.3 cal ka BP (Unit 3). Sediments of Unit 4 overlay Units 1 to 3, are coarser and display regular foresets and oblique-bedding, suggesting deposition in riverine environments after installation of the Shire River ( $\sim 5.5-5.0 \mathrm{ka} \mathrm{BP})$. Freshwater mollusk assemblages and bioturbation regularly occur in the lacustrine sediments, but are largely absent from Unit 4. Diverse and often contradicting hypotheses on the lake levels of Lake Malawi have been proposed for the early and middle Holocene. The Chipalamawamba Beds allow straightforward recognition of water levels and provide strong evidence for oscillating lake levels during this period, rather than continuous high or low levels. Sedimentation rates have been high and individual shell beds have typically been deposited during a few decades. Because the Chipalamawamba Beds contain a sequence of mollusk assemblages with intervals between subsequent shell beds ranging from a century to a few millennia, they enable paleontological analysis of the fauna with an unusually high temporal resolution. That some mollusk lineages inhabiting Lake Malawi are in the early stages of diversification and radiation increases the paleobiological relevance of these beds.
\end{abstract}

\section{Introduction}

In this paper we describe a sedimentary sequence in the Mangochi Province of Malawi that was deposited in long-lived Lake Malawi during the early to middle Holocene. These sediments were first visited for scientific purposes in 1992 by Albrecht Gorthner as collaborator of the paleontological and paleoanthropological Hominid Corridor Research Project under the direction of Friedemann Schrenk. Although Gorthner touched upon the beds in the scientific literature (Gorthner, 1994), hardly any information he collected during his single day of fieldwork in the area was published, apart from an abbreviated overview of the freshwater mollusk fossils. A preliminary draft on some stratigraphic and sedimentological aspects of the beds was composed, but never published (A. Gorthner, personal communication, 2012).

We visited the region again in 2008 and in 2010, during which we dug new trenches, found additional outcrops and collected sufficient data on the sediments as well as their fossil content for a detailed description of the stratigraphy of the beds, their depositional paleoenvironment and paleoecology. Moreover, we outline some paleolimnological implications of the data collected and indicate the potential these sediments offer to study organismal diversification events in long-lived Lake Malawi.

\subsection{General setting}

The strata that we newly describe as the Chipalamawamba Beds crop out some $10 \mathrm{~km}$ south of Lake Malawi along the shores of the upper Shire River, just north of the shallow 
Lake Malombe located farther south (Fig. 1). The main outcrops are located on the western shore nearby the fishing villages Chipalamawamba and Kwitambo at the eroding side of a bend in the Shire River, but also on the eastern bank of the next curve in the river farther upstream, nearby the poorly accessible village of Kazembe. Currently no other outcrops have been discovered along the upper Shire River, but the beds may cover a wider geographical area, as suggested by the topography and bathymetry of the Malawi Basin in the south (Scholz and Rosendahl, 1988). We encountered sediments and mollusks belonging to Chipalamawamba strata nearby a graveyard of Chipalamawamba, $\sim 600 \mathrm{~m}$ inland and north of the village centre (Fig. 1c). On the central plaza, sediments were brought to the surface recently (2009) during the construction of a new water hole, but they appear to have been discarded and hence were not available for examination. However, the old, southerly water hole exposed sediments of the Chipalamawamba Beds. These findings indicate that the sediments directly beneath the modern soil on which Chipalamawamba and the southward village Kwitambo are built belong to the Chipalamawamba Beds. On a broader geographical scale, Gorthner (unpublished data) suggested that very similar outcrops were present nearby Palm Beach, however, upon prospecting his locality no such outcrops have been identified there. Crossley and DavisonHirschmann (1982) reported several Holocene beach ridges along the western shores of Lake Malawi, some of which correspond to the high lake level phases that resulted in the deposition of the Chipalamawamba Beds, but for most of these beach ridges dates are not available and quite a few of them apparently were deposited in the last $2 \mathrm{ka}$. All of these beach ridges are of similar height or topographically lower than the outcrops along the upper Shire River. However, none of the other early to middle Holocene deposits known has a depositional continuity and paleobiological relevance comparable to the Chipalamawamba Beds.

Our descriptions of the Chipalamawamba Beds here are based on detailed studies of the main sections on the western shore of the Shire River along Chipalamawamba and Kwitambo. These outcrops cover a horizontal distance of $\sim 1200 \mathrm{~m}$, and crop out from the water level up to $\sim 5.0 \mathrm{~m}$ higher. On the eastern shore of the Shire at Kazembe, outcrops are present over a distance of $\sim 170 \mathrm{~m}$ and have a smaller vertical elevation (from the water level up to $\sim 3.0 \mathrm{~m}$ above it). These latter outcrops are not treated in detail here because no sections were made through them and their stratigraphy has not been studied as extensively.

\section{Material and methods}

\subsection{Field methods}

During fieldwork in 2008 we mainly aimed to collect fossils from outcrops and to characterize the depositional en- vironments under which fossil-bearing strata were formed. Because of the considerable lateral variation observed in the beds, it soon became clear that the data collected during this short visit were insufficient to study fossil material in chronological sequence using time series analyses. Therefore, we decided to undertake a more intensive field campaign in 2010 to elucidate the stratigraphy, to characterize the sedimentology and to elaborate our sampling of fossil material.

We dug step-like trenches through the Chipalamawamba Beds to enable detailed stratigraphical and sedimentological descriptions and to measure and record the characteristics of individual beds. Some images of the exposures and trenches are provided in Fig. 2. For each section a lithostratigraphic profile was constructed. Due to the proximity of the highly populated villages and the regular visits people make to the waterside, we dug trenches at dawn, fully documented and sampled them over the day to close them again before dark. Vertical positions of trench steps and bedding planes were measured with an accuracy of $\sim 1 \mathrm{~cm}$ relative to the water level of the river $(\sim 473-474 \mathrm{~m}$ a.s.l.). For this we used baseline nails, a theodolite (Sokkisha C3E, 22× optical magnification; accuracy $\sim 0.001$ gon) and beacon. The water level was observed to fluctuate up to $\sim 5 \mathrm{~cm}$ during the day and sometimes even more depending on wind stress. We kept a constant baseline by marking the water level with nails at each locality and comparing the positions of nails and the water level at previously established stations at the time of creating a baseline for a new locality. With this procedure $1 \mathrm{~cm}$ in accuracy may have been lost additionally. Given the relatively small distances between theodolite and beacon $(<50 \mathrm{~m})$ no correction for the curvature of the earth was required. At each baseline nail GPS coordinates were taken with a Garmin GPS III Plus to allow calculation of distances between individual profiles. Sometimes, distances between trenches and/or outcrops were directly measured using tape measure or with the theodolite and beacon. Comparison of GPS-based measurements with these latter methods suggests distances between subsequent trenches are recorded with an accuracy of $\sim 2 \mathrm{~m}$.

Stratigraphical profiles were drawn on a $1 / 10$ scale and include information on grain size, sorting, sediment color, sedimentary structures, the fossil content of the beds and the nature of the stratigraphical contacts. Granulometry was determined by visual comparison with a grain chart (Krynine, 1948) at $10 \times$ magnification; colors were determined using the revised Standard Soil Color Charts (Oyoma and Takehara, 1967). Every $5 \mathrm{~cm}$, magnetic susceptibility (MS) was measured using a ZH instruments SM-30 meter at the shady side of the profile. The accuracy is $1 \times 10^{-7}$ SI units and measurements were performed with double calibration in the air (before and after). Each measurement was repeated three times, but if differences were larger than $0.40 \times 10^{-4}$ SI units, 2 additional measurements were taken. As MS is temperature-dependent, temperatures were measured for every step in the trench. However, because limited fluctuations 


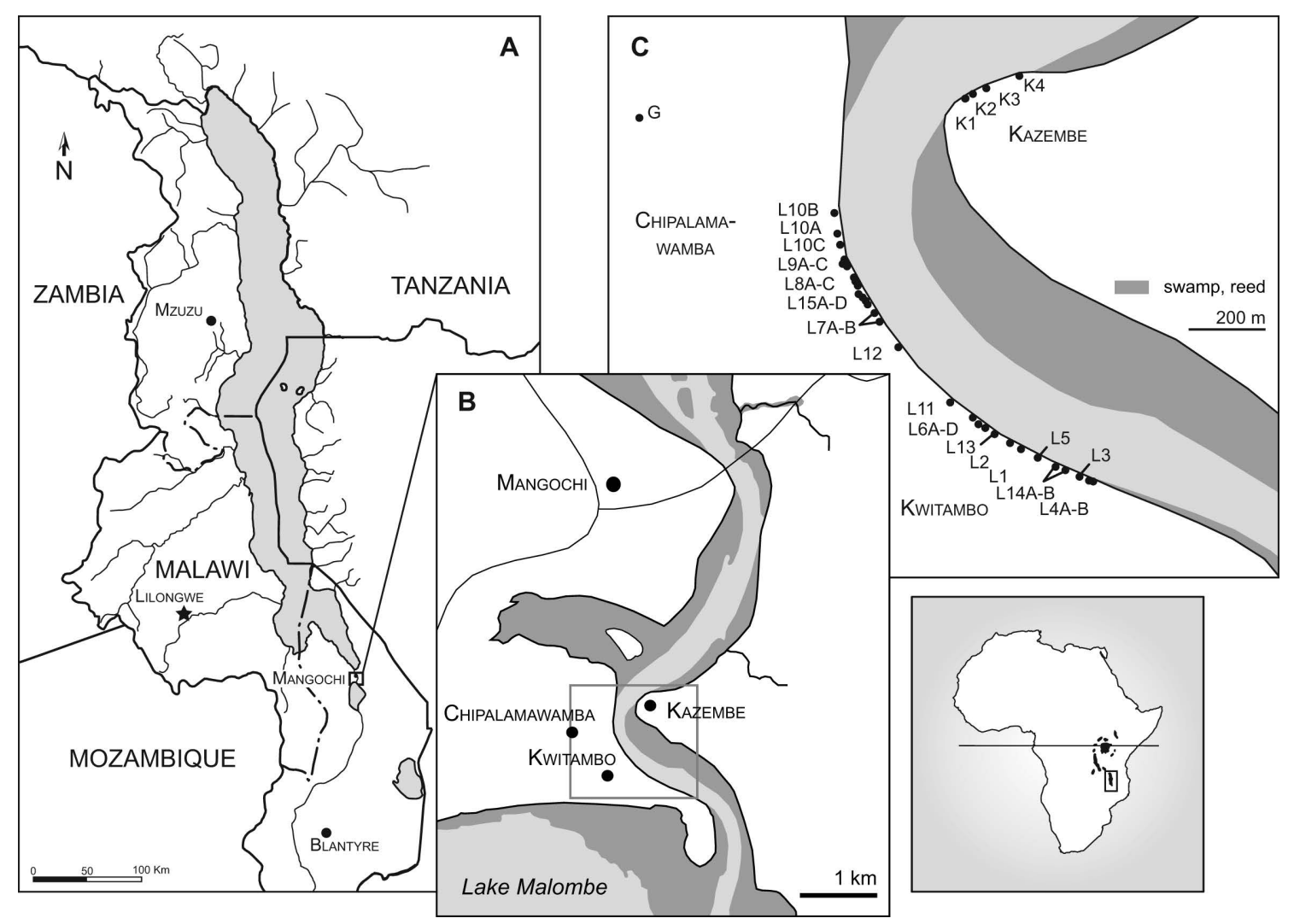

Fig. 1. (A) Lake Malawi with inflowing rivers illustrating the small catchment of the Malawi Basin. (B) The Mangochi region between Lake Malawi and Lake Malombe; the study area in the grey rectangle is enlarged in (C). (C) Outcrops nearby Chipalamawamba, Kwitambo and Kazembe with their locality codes. G indicates Chipalamawamba sediments dug up by locals at the graveyard.

in temperature were measured during MS measurements, no temperature correction was needed. Sediment samples were taken every 5 or $10 \mathrm{~cm}$ with tubes of $\sim 3 \mathrm{~cm}^{3}$ for later sedimentological analyses in the lab. At locality L1 a continuous sediment profile was taken as well, but as this method proved suboptimal (and highly time-consuming) in the loosely aggregated sandy sediments at Chipalamawamba, it was not performed for other trenches.

Shell beds, when present, were sampled individually in a qualitative and/or quantitative way (by weighing the sample and subsequently sieving it using mesh sizes of $2 \mathrm{~mm}$ and $710 \mu \mathrm{m})$. Taphonomic features were recorded. A few poorly preserved and/or scattered shell beds were not sampled, though their position is indicated in the profile drawings, with summary indications as to their content. In situ samples of fossils were collected during the digging of the trenches only if the exact stratigraphical position could be established. However, fossils of uncertain positions were screened and when they displayed interesting or unusual features, they were bagged as ex situ. Otherwise, material was only collected during the cleaning and profile-drawing phases. Quantitative samples were sieved after dark and profiles were re-drawn and correlated with earlier profiles. If re- quired or desirable, additional semi-trenches were dug the next day to verify physical correlations or other aspects that proved ambiguous in the re-drawing phase.

\subsection{Lab methods}

\subsubsection{Sedimentology and stratigraphy}

Re-drawn sediment profiles were digitized primarily using SedLog v2.1.4. (Zervas et al., 2009), after which the result was imported in Adobe Illustrator CS5 to make the initial digitization result more condensed and accurate, e.g., by expanding the available set of stratigraphical contacts in SedLog, by not just indicating the fossil content of a bed, but placing symbols at their exact vertical position of occurrence in the profile, and by designing swatches that indicate minimal and maximal grain sizes, and therefore the degree of sorting in a sediment layer. Also, MS measurements were compiled and plotted in profiles using Excel. These values were compared on a profile to profile base (not shown). Google Earth was also used to prepare the figures.

To create overview figures, digitized individual profiles were downsized and compiled in two graphs, one for the northern and one for the southern part of the outcrops on 


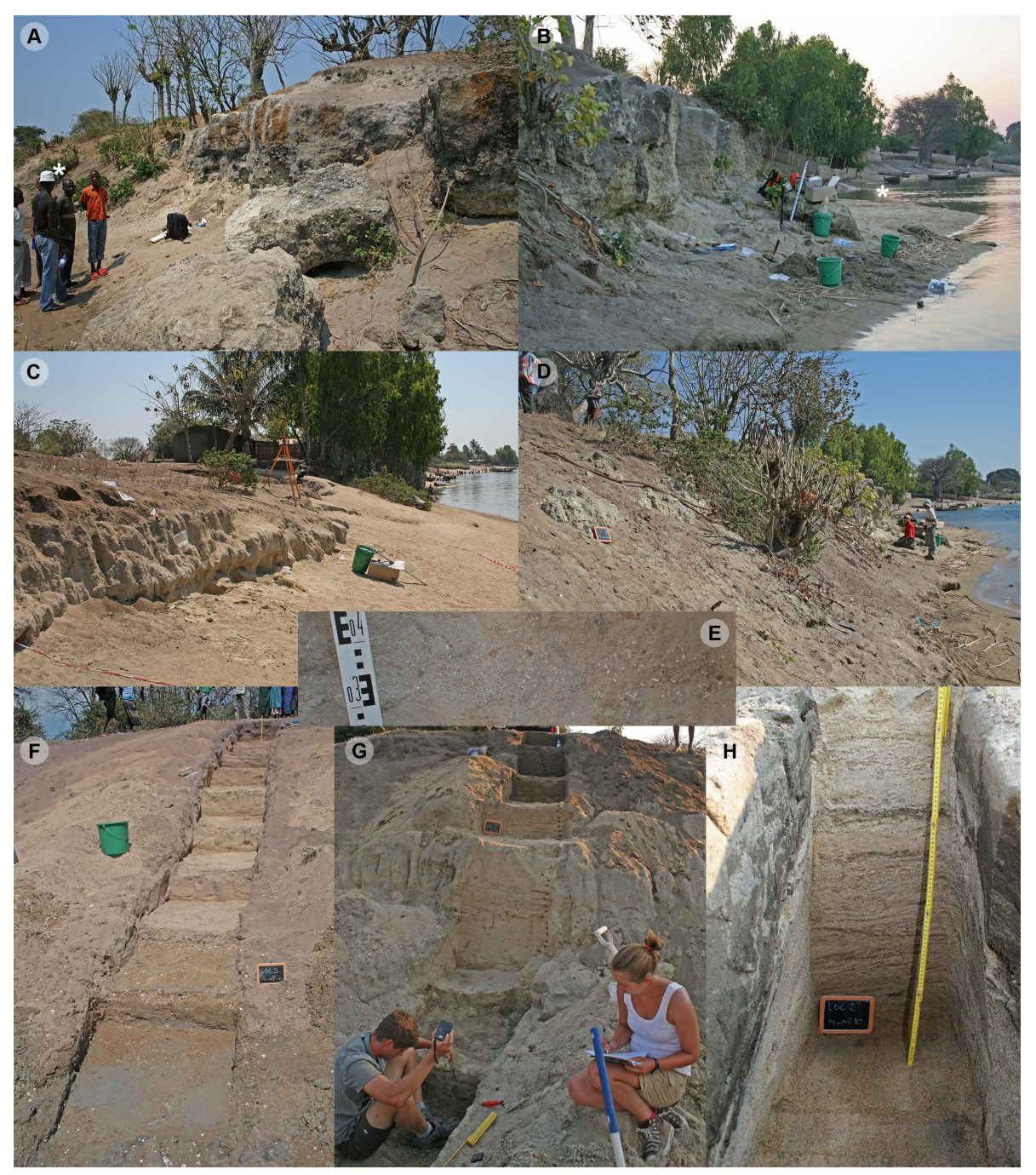

Fig. 2. Outcrop pictures: rocky outcrop of locality L8B in 2008 (A) and 2010 (B), showing that since 2008 considerable erosion took place in the basal part of the outcrop; (C) outcrops at L9B overlain by modern soil; (D) outcrops at L8A showing that eroded sediments of the modern soil cover up most of the Chipalamawamba Beds; (E) section through the middle Melanoides shell bed at L1 (the bed from which samples 10-089, 10-095 and 10-025Q in Fig. 5 were taken); (F) trench at L5, with shell beds mainly occurring near the base (slightly above and below the little blackboard to the right of the trench); $(\mathbf{G})$ trench at L9A, with the modern soil at the top (upper 2.5 steps) being distinctively darker in color, students are measuring magnetic susceptibility and sediment samples were taken earlier; (H) lower section of L12 $(\sim 0.0-0.9 \mathrm{~m}$ above water level), showing the coarser sediments of Unit 4 with numerous foresets. Little blackboard, people and equipment for scale. The asterisk $(*)$ in $(\mathbf{A})$ indicates the position from which $(\mathbf{B})$ was photographed and vice versa.

the western shore of the Shire River. Subsequently, correlations were synthesized and information on erosional phases was added. Several arguments for correlations exist; some are based on observed physical continuation of beds, other correlations are based on geographical proximity and similarities in the mollusk composition of fossil assemblages and the taphonomy of the shell beds, others are deduced by similarities in grain size, sediment color and peaks in the MS values, and finally some correlations are based on ages as measured via radiocarbon dating. The symbols used and the diverse types of correlations made in these overview figures are summarized in Fig. 3.

\subsubsection{Radiocarbon dating}

Radiocarbon dates were performed on fossil freshwater mollusks. Therefore, calibration requires taking account of the reservoir effect in mollusk shells caused by sources of fossil carbon in the Malawi Basin. Dating sub-recent bulk organic material, Brown et al. (2007) found a reservoir effect of $\sim 400 \mathrm{yr}$. This corresponds well to the offset of $\sim 450 \mathrm{yr}$ obtained by comparison of dates on bulk organic material and varve counting ages of Holocene sediments (Barry, 2001). However, comparisons between bulk organic material and woody material (mid-Holocene) or charcoal 


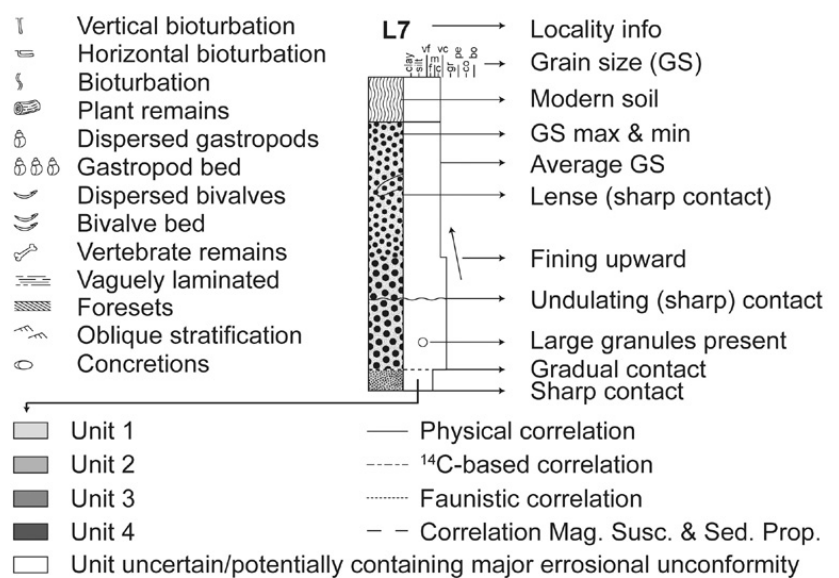

Fig. 3. Legend to the symbols and the diverse types of correlations between profiles used in Figs. 4 and 5.

(Last Glacial Maximum) suggest a larger effect of reworked carbon $(770 \pm 100$ and $680 \pm 110 \mathrm{yr}$; Barry et al., 2002). Because the origin of bulk organic material is obscure, it is difficult to interpret the obtained differences. Brown et al. (2007) adopted a constant reservoir effect of $450 \mathrm{yr}$ during the Holocene. Their assumption that the reservoir effect remained fairly constant over the Holocene seems reasonable given the geological brevity, the limited tectonic changes in the Malawi Basin over this period, and the long flushing times of the lake ( $750 \mathrm{yr}$; Bootsma and Hecky, 1993). However, as the reservoir effect in bulk organic material can hardly be related to those recorded in other sources of datable material, we dated an early 20th century shell from Lake Malawi to allow calibration of our other radiocarbon dates. This specimen was obtained from the Royal Museum for Central Africa (Tervuren, Belgium; MRAC 58430, Bequaert 1927). Calibrations were performed using the "Fairbanks 0107" calibration curve (Fairbanks et al., 2005).

\subsubsection{Fossils}

The content of most fossil samples (98\%) has been identified to the lowest possible taxonomic rank. Freshwater mollusks are overwhelmingly dominant and we identified these using Mandahl-Barth (1972) and Brown (1994). Identifications and specimen counts were compiled in an excel database.

\section{Results}

\subsection{Sedimentological characteristics}

In total, 20 large trenches and 10 smaller trenches (L6C \& D, L8C, L9B \& C, L10C, L14B, L15B-D) were made. The smaller ones were necessary to investigate the lateral continuity of stratigraphic contacts (locations indicated in Fig. 1). General sedimentological and stratigraphical overviews of the Chipalamawamba Beds are presented in Fig. 4 for the northern part and in Fig. 5 for the southern part. Most beds contain medium, coarse and very coarse sandy sediments that regularly contain larger granules, i.e. pebbles with diameters of 3-9 $\mathrm{mm}$ and very occasionally up to $20-25 \mathrm{~mm}$. Overall, sediments have been deposited rapidly (see below) in moderate to high energy environments. A few beds with large granules and rolled shells reflect very high energy conditions. The color of the sediments ranges from yellowish for the more typical lacustrine beds (frequently $2,5 \mathrm{Y} 7 / 3$ light YE, 2,5 Y 8/3 pale YE, 2,5 Y 6/3 dull YE or even 2,5 Y $6 / 2$ (greyish) YE) to somewhat darker brown/dull yelloworange sediments in beds that seem often (but not always) to have been deposited in environments with slightly more energy (frequently 10 YR 5/4-7/3 dull YE BR or dull YE OR). The modern soil overlying the Chipalamawamba Beds is always easily recognizable, mainly by its darker color (10 YR 3/2 (brownish) BL; see e.g., Fig. 2c and g) and its higher magnetic susceptibility (on average $\sim 0.13 \times 10^{-3} \mathrm{SI}$ ) than the Chipalamawamba sediments (on average $\sim 0.05 \times 10^{-3}$ SI). Noteworthy is that beds just below the modern soil were always darker brown or dull yellow-orange and that more yellowish sediments were dominant in L15 and profiles north of it, whereas profiles farther south had often relatively darker orange/brown sediments. Paleo-river gullies are recognizable by their infill with uniformly coarse and dull yellow-orange/dull yellow-brown (mainly 10 YR 7/37/4) sediments that generally lack fossils. They often display oblique bedding and foresets (e.g., Fig. 2h). Elsewhere foresets and oblique bedding is more occasionally present and often associated with bioturbation, fossil remains and concretions.

\subsection{Radiocarbon dating}

In total 23 dates have been obtained on fossil freshwater mollusk shells from the Chipalamawamba Beds (Table 1). One date was obtained by Gorthner (1994) and although we have approximate information as to what shell bed yielded the material, we have no information on the lab and dating codes, if and how he calibrated the date and whether he attempted to account for the reservoir effect. Therefore, we report his result here, but leave it untouched for all other purposes. We performed the remaining 22 dates on shells that have a well-constrained stratigraphic position. All results are internally consistent and are reported in Table 1 together with the date obtained on a modern shell for calibration. This modern shell with an age of 25 a BP yielded a radiocarbon age of $190 \pm 30{ }^{14} \mathrm{C}$ a BP, suggesting that the reservoir effect in mollusks is $\sim 175 \mathrm{yr}$, hence substantially smaller than that recorded in bulk organic material. 


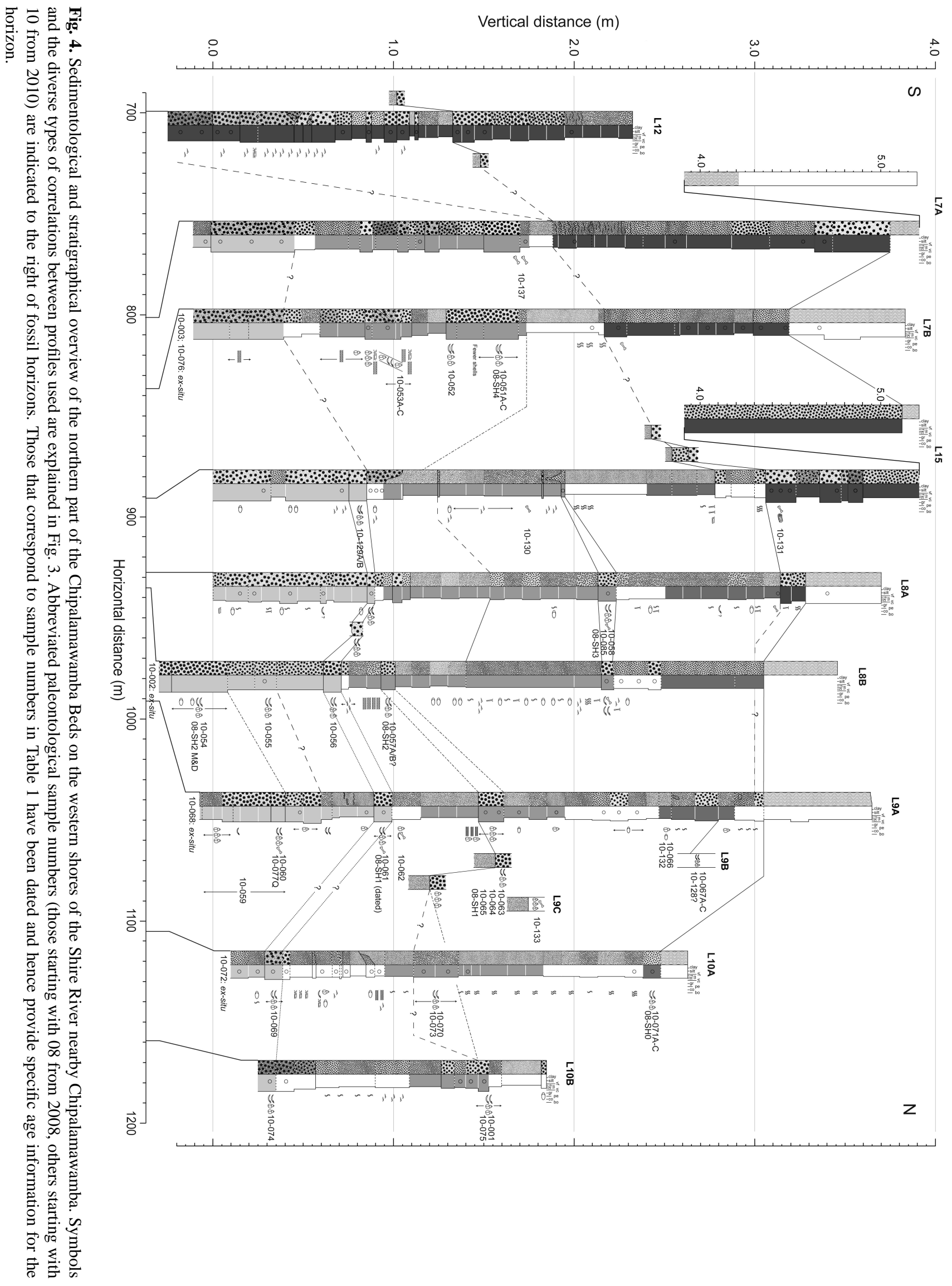




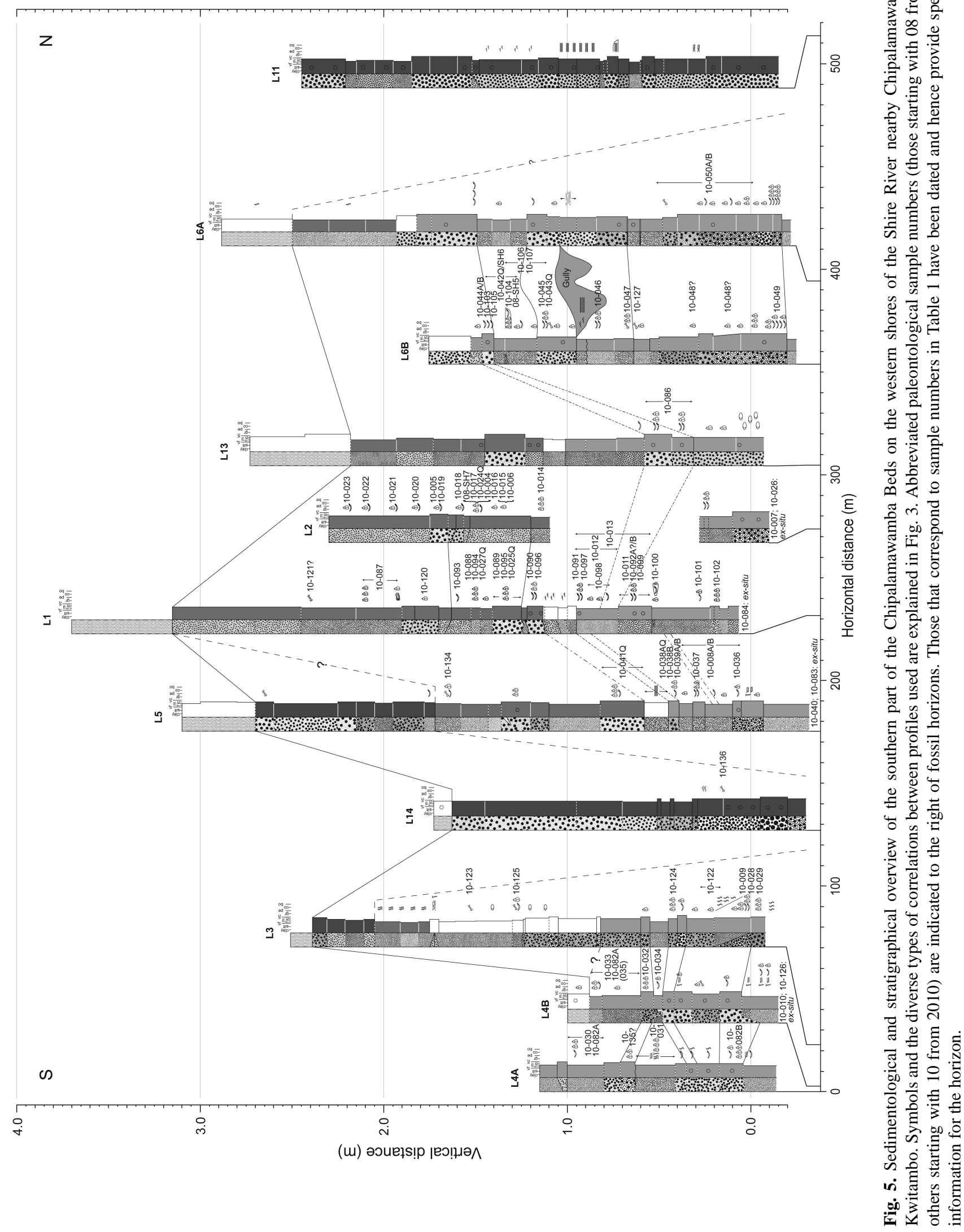


Table 1. Radiocarbon dating results for 23 fossil mollusk samples from the Chipalamawamba Beds and one modern shell. Dating of this modern shell (Dating number 1) resulted in a reservoir effect of $\sim 175 \mathrm{yr}$, which has been used to calibrate the other dates from radiocarbon to calendar age. All MLW-BVB-08 (2008) and MLW-BVB-10 (2010) sample codes are linked to specific shell horizons in Figs. 4 and 5, except for 10-078 and 10-080, which were obtained from outcrops on the eastern shore near Kazembe.

\begin{tabular}{rlllcc}
\hline Dating\# & Lab\# & Sample\# & Material & ${ }^{14}$ C age (BP) & Calendar age (BP) \\
\hline 1 & Beta-316041 & MRAC-58430 & Chambardia shell & $190 \pm 30$ & 25 \\
2 & Poz-31571 & MLW-BVB-08-SH5 & Aspatharia shell & $6240 \pm 40$ & $6918 \pm 53$ \\
3 & Poz-31573 & MLW-BVB-08-SH4 & Coelatura shell & $6675 \pm 35$ & $7420 \pm 24$ \\
4 & Poz-31574 & MLW-BVB-08-SH1 & Coelatura shell & $9090 \pm 50$ & $10081 \pm 109$ \\
5 & Poz-30524 & MLW-BVB-08-SH0 & Lanistes shell & $5290 \pm 40$ & $5874 \pm 52$ \\
6 & Poz-30525 & AG-2.8.92-8.205 (eq. 08-SH7) & Melanoides shells & $4795 \pm 35$ & $5348 \pm 57$ \\
7 & Poz-42241 & MLW-BVB-10-099 & Coelatura shell & $6400 \pm 35$ & $7149 \pm 54$ \\
8 & Poz-42242 & MLW-BVB-10-091 & Chambardia shell & $6050 \pm 35$ & $6688 \pm 36$ \\
9 & Poz-42243 & MLW-BVB-10-028 & Coelatura shell & $6760 \pm 60$ & $7478 \pm 48$ \\
10 & Poz-42244 & MLW-BVB-10-035 & Lanistes shell & $6300 \pm 40$ & $6996 \pm 62$ \\
11 & Poz-42246 & MLW-BVB-10-038B & Coelatura shell & $6040 \pm 35$ & $6678 \pm 36$ \\
12 & Poz-42247 & MLW-BVB-10-050A & Corbicula shell & $6560 \pm 35$ & $7308 \pm 42$ \\
13 & Poz-42248 & MLW-BVB-10-052B & Coelatura shell & $6790 \pm 40$ & $7501 \pm 38$ \\
14 & Poz-42249 & MLW-BVB-10-053 & Coelatura shell & $6980 \pm 40$ & $7642 \pm 32$ \\
15 & Poz-42250 & MLW-BVB-10-058 & Coelatura shell & $6080 \pm 40$ & $6718 \pm 44$ \\
16 & Poz-42251 & MLW-BVB-10-057A & Coelatura shell & $6185 \pm 35$ & $6847 \pm 51$ \\
17 & Poz-42256 & MLW-BVB-10-054 & Coelatura shell & $9550 \pm 50$ & $10594 \pm 63$ \\
18 & Poz-42257 & MLW-BVB-10-065 & Coelatura shell & $6200 \pm 40$ & $6867 \pm 56$ \\
19 & Poz-42258 & MLW-BVB-10-077 & Coelatura shell & $9580 \pm 50$ & $10630 \pm 66$ \\
20 & Poz-42259 & MLW-BVB-10-075 & Coelatura shell & $6200 \pm 40$ & $6867 \pm 56$ \\
21 & Poz-42261 & MLW-BVB-10-086 & Coelatura shell & $6190 \pm 40$ & $6853 \pm 56$ \\
22 & Poz-42262 & MLW-BVB-10-080 & Coelatura shell & $8910 \pm 50$ & $9695 \pm 93$ \\
23 & Beta-316041 & MLW-BVB-10-078 & Coelatura shell & $5880 \pm 30$ & $6479 \pm 36$ \\
24 & Gorthner & Sample 10(AG-2.8.92-10) & bivalve shell & & $5845 \pm 85$ \\
\hline & & & &
\end{tabular}

\subsection{Fossil content}

Including replicates, 163 samples of fossil material were obtained during the fieldwork campaigns in 2008 (17) and 2010 (146). Most of these fossils belong to freshwater mollusks, but fish bones and occasionally isolated mammal or bird remains have also been obtained. The fossil assemblages testify to the exclusively aquatic setting in which the Chipalamawamba Beds were deposited. The content of all but three of these samples has been fully identified and counted. In total this results in 34215 specimens being processed, leaving about 10000-15000 more specimens yet to be handled (mainly belonging to the gastropod genus Melanoides). However, even though not all material has been processed, it was possible to make preliminary comparisons of samples and their mollusk assemblages. Table 2 provides an overview of the fossil finds in comparison to the modern fauna. It indicates that two mollusk genera currently present in Lake Malawi have not been recovered as fossils, whereas three genera present in the fossil record are not currently considered to occur in Lake Malawi. The diverse fossil assemblages in Units 1 to 3 testify to the lacustrine nature of the deposits. Detailed discussions on mollusk diversity through time is beyond the scope of this paper, but very characteristic assemblages could be distinguished in a few cases and allowed correlations between profiles. Because some mollusk genera display considerable morphological change over the Holocene, some characteristics of fossil taxa enabled us to attribute shell beds to a particular stratigraphic unit. This aspect will be discussed below.

\subsection{Stratigraphy}

The Chipalamawamba Beds consist of four units separated from one another by erosional contacts, which unfortunately are not always easy to recognize in the field. They are overlain by modern soil. The bedding is usually nearly horizontal, often dipping slightly towards the north, but due to the lenticular nature of the beds, variation occurs and dips to the south have been observed as well. Below, we describe these four units from bottom to top and have delineated, to the extent possible, the four major units in the grain size column of the profiles in Figs. 4 and 5. Magnetic susceptibility by itself did not allow discerning the units of the Chipalamawamba Beds because the variation within a bed is usually similar to or greater than that between beds. As MS properties are not characteristic for the individual units, they are not discussed below and peaks in MS values are used for correlation only in 
Table 2. Fossil finds in the units of the Chipalamawamba Beds compared to the modern mollusk fauna of the Malawi Basin (updated from Mandahl-Barth, 1972). Numbers indicate how many morphospecies are recognized per genus; one asterisk $(*)$ marks the number of morphs after inclusion of fossil material collected by A. Gorthner; two (**) indicates that deep-water species are included. Mollusk finds not identifiable to genus level were excluded. Doubtful occurrences in the Malawi Basin are flagged with question marks, vc $=$ very common, $\mathrm{c}=$ common, $\mathrm{uc}=$ uncommon, $\mathrm{r}=$ rare, $\mathrm{a}=$ absent.

\begin{tabular}{|c|c|c|c|c|c|}
\hline Taxon & Unit 1 & Unit 2 & Unit 3 & Unit 4 & Modern \\
\hline \multicolumn{6}{|l|}{ Gastropoda Caenogastropoda } \\
\hline Bellamya & $1, \mathrm{c}$ & $1, \mathrm{c}$ & $1, \mathrm{c}$ & $\mathrm{a}$ & $4 * *$ \\
\hline Lanistes & $2, \mathrm{c}$ & $3\left(4^{*}\right), \mathrm{c}$ & $3, \mathrm{uc}$ & $\mathrm{a}$ & $5 * *$ \\
\hline Gabbiella & $1, \mathrm{c}$ & $1, \mathrm{c}$ & $1, \mathrm{c}$ & $\mathrm{a}$ & 1 \\
\hline Melanoides & $8, \mathrm{vc}$ & $8, \mathrm{vc}$ & $8, \mathrm{vc}$ & $\mathrm{a}$ & 9 \\
\hline \multicolumn{6}{|l|}{ Gastropoda Heterobranchia } \\
\hline Anisus & $\mathrm{a}$ & $\mathrm{a}$ & a & $\mathrm{a}$ & 1 \\
\hline Biomphalaria & $1, \mathrm{r}$ & a & a & a & $1 ?$ \\
\hline Bulinus & $2, \mathrm{c}$ & $3, \mathrm{c}$ & $3, \mathrm{c}$ & $\mathrm{a}$ & 4 \\
\hline Ferrissia & $\mathrm{a}$ & $1, \mathrm{r}$ & $\mathrm{a}$ & $\mathrm{a}$ & 0 \\
\hline Gyraulus & $\mathrm{a}$ & $\mathrm{a}$ & a & a & 1 \\
\hline Segmentorbis/Lentorbis & $\mathrm{a}$ & $1, \mathrm{r}$ & a & a & 0 \\
\hline \multicolumn{6}{|c|}{ Bivalvia Heterodonta (Veneroida) } \\
\hline Pisidium & $1, \mathrm{uc}$ & $1, \mathrm{uc}$ & a & a & 2 \\
\hline Sphaerium & $\mathrm{a}$ & $1, \mathrm{r}$ & a & $\mathrm{a}$ & 0 \\
\hline Corbicula & $1, \mathrm{c}$ & $1, \mathrm{c}$ & $1, \mathrm{c}$ & a & 1 \\
\hline \multicolumn{6}{|c|}{ Bivalvia Heterodonta (Unionoida) } \\
\hline Coelatura & $2, \mathrm{c}$ & $2, \mathrm{c}$ & $1, \mathrm{c}$ & $\mathrm{a}$ & $2(3 ?)$ \\
\hline Mutela & $1, \mathrm{r}$ & $1, \mathrm{r}$ & $\mathrm{a}$ & $\mathrm{a}$ & 1 \\
\hline Chambardia & $1, \mathrm{r}$ & $1, \mathrm{r}$ & $\mathrm{a}$ & $\mathrm{a}$ & $1(2 ?)$ \\
\hline \multicolumn{6}{|l|}{ Vertebrata } \\
\hline fish bones/teeth & $\mathrm{r}$ & $\mathrm{r}$ & $\mathrm{r}$ & $\mathrm{r}$ & - \\
\hline reptile teeth & $\mathrm{r}$ & $\mathrm{r}$ & $\mathrm{a}$ & $\mathrm{a}$ & - \\
\hline bird bones & a & $\mathrm{r}$ & a & $\mathrm{a}$ & - \\
\hline mammal bones/teeth & $\mathrm{a}$ & $\mathrm{r}$ & a & $\mathrm{a}$ & - \\
\hline
\end{tabular}

cases of correspondence with independent sedimentological evidence.

We describe the stratigraphy in informal terminology (beds and units instead of formations and members) because of uncertainties in the geographic (and cartographic) extent beyond Chipalamawamba, Kwitambo and Kazembe, because of the difficulties experienced in identifying some of the erosional contacts between the units, and because the base of the Chipalamawamba Beds and the (horizontal and vertical) extension of the paleo-river gullies remain unknown.

\subsubsection{Unit 1}

Unit 1 is the lowermost unit and dates back to 10.6$9.7 \mathrm{cal} \mathrm{kaBP}$. Its contact with the underlying unit was not observed; the upper boundary is an erosional contact with Unit 2. Unit 1 has an observed thickness of $1.0 \mathrm{~m}$, but is thicker as its base was not observed. Sediments are generally poorly sorted; they contain both fine and coarse sand and often include larger granules (e.g., in the top shell bed of the unit). Bioturbation and oblique stratification sometimes occur.

The unit is present in profile L15 and all profiles north of it; it probably even extends south of L15 in profiles 7A and 7B. South of L7B, Unit 1 is eroded by a major paleo-gully. The youngest sediments of this unit thus far known are recognized at Kazembe. Fossil mollusk assemblages are very common in Unit 1 and can easily be discerned from those of other units by the dominant Melanoides cf. polymorpha morphotype (Fig. 6a-c) and the abundant M. cf. nyassana (Fig. 6d). These morphotypes have a medium to strong shoulder, a high apex and are smooth (not tuberculated).

\subsubsection{Unit 2}

Sediments belonging to this unit were deposited some 7.6$6.5 \mathrm{cal}$ ka BP. The lower boundary is an erosional unconformity topping Unit 1 . While the sediments that contain this erosional unconformity are well-recognized, e.g., by oblique stratification, it is difficult to pinpoint the erosional surface that is responsible for the main time gap between deposition 


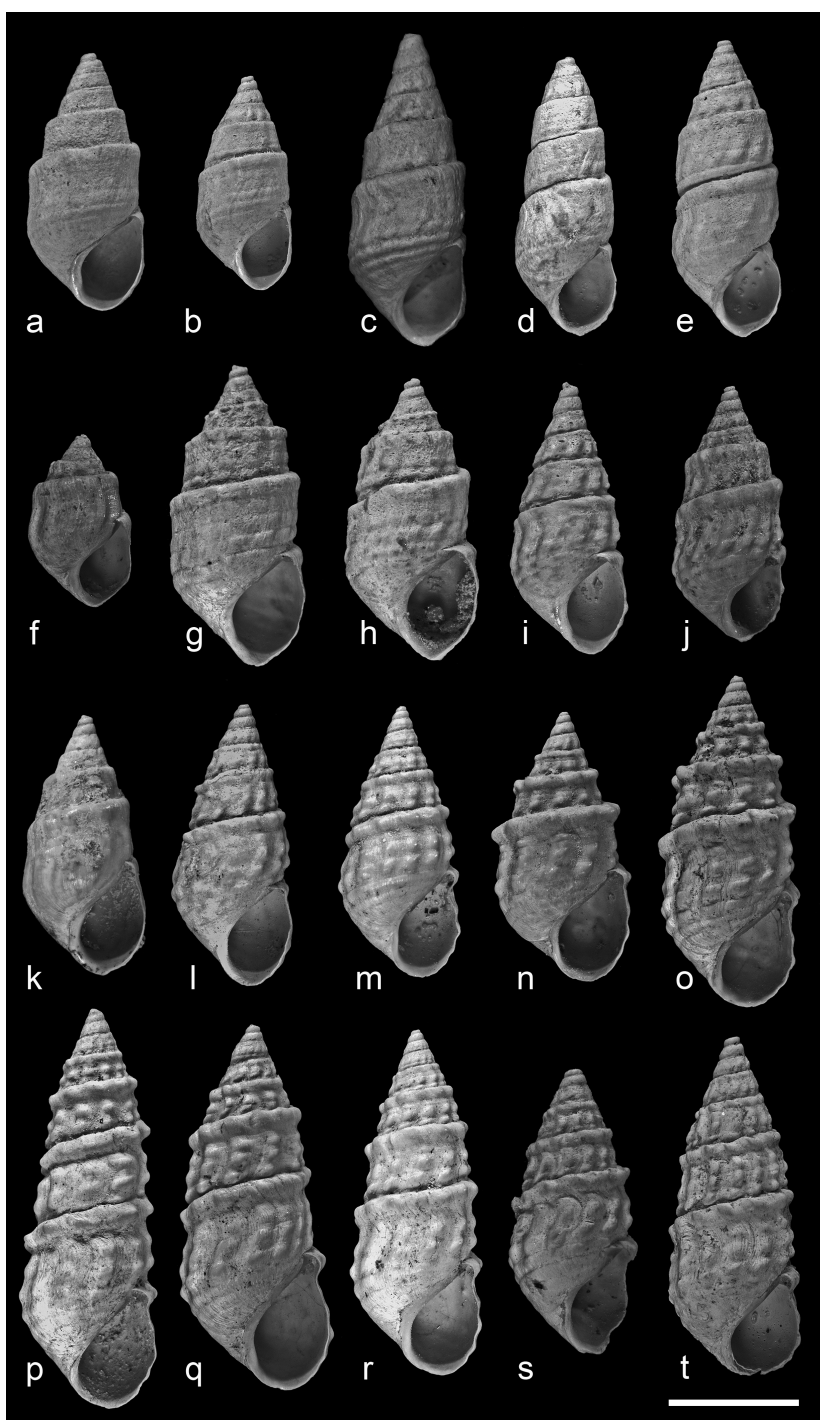

Fig. 6. Melanoides specimens from the Chipalamawamba Beds. The first two rows represent material from Unit 1, with much weaker ornamentation than specimens from Units 2 and 3 (lower two rows). In Unit $1, M$. cf. polymorpha (A-C) is very abundant, and $M$. cf. nyassana (D) occurs regularly too. Specimens of $M$. pupiformis (E) and of $M$. cf. turritispira $(\mathbf{F}-\mathbf{J})$ are not that abundant and more weakly ornamented than these taxa are in Units 2 and 3. The more strongly ornamented $M$. cf. turritispira (I-J) are rare in Unit 1. M. cf. polymorpha $(\mathbf{K})$, initially common in Unit 2, is becoming rarer ( $\sim 5 \%$ of all Melanoides) higher up, and even more so in Unit 3; $M$. cf. nyassana is rare $(<1 \%)$ in Units 2 and 3. $M$. cf. turritispira is more strongly ornamented in Unit $2(\mathbf{L}-\mathbf{N})$ and 3 (S) than in Unit 1, as is M. cf. pupiformis (Unit 2: O-R; Unit 3: T). Strongly ornamented $M$. cf. turritispira specimens are more abundant in Unit 3 than in Unit 2, but specimens of Unit 3 are generally more poorly preserved than those of Unit 2 . Scale bar is $5 \mathrm{~mm}$. of sediments of Unit 1 and Unit 2. Unit 2 has an average thickness of about $1.0 \mathrm{~m}$ in the north (L10-L7A), but in L6 it reaches a thickness of $2.0 \mathrm{~m}$, diminishing again in thickness towards the south (L4), where it remains about $1.3 \mathrm{~m}$ thick. There is hence a lot of lateral variation and at the same elevation substantial differences in ages exist laterally. Several local diastems and evidence for short erosional phases have been recorded in Unit 2, as evidenced by a minor gully a few meters wide that we observed between L6A and L6B. Overall, the sediments of Unit 2 are well-sorted and very yellowish; shell beds are relatively abundant and typically occur in the coarser-grained, often darker colored beds.

Unit 2 has the widest geographical distribution within the Chipalamawamba Beds. It occurs in all profiles on the western shore, except for those taken in the two main paleo-gullies. Its youngest strata occur at Kazembe. The Melanoides community in shell beds of Unit 2 is dominated by a medium to strongly tuberculated $M$. cf. turritispira morphotype (Fig. 61-n), which is about the same size as the $M$. cf. polymorpha morphotype in Unit 1 and is very closely related to it (Mandahl-Barth, 1972; Genner et al., 2007). $M$. cf. pupiformis has evolved strongly sculptured shells too (Fig. 6o-r).

\subsubsection{Unit 3}

Radiocarbon dating on mollusk shells from sediments of Unit 3 resulted in ages of $\sim 5.9-5.3 \mathrm{cal} \mathrm{ka} \mathrm{BP.} \mathrm{More} \mathrm{dates} \mathrm{are}$ required to elucidate whether these sediments have been deposited during one or two transgressions. Currently, different ages have been obtained from geographically separated outcrops. It has been more difficult to trace the main erosional surface(s) between Units 2 and 3, compared to the one between Units 1 and 2, but the white layers between Units 2 and 3 in Figs. 4 and 5 identify the sediments that may contain such surface(s). The upper boundary of Unit 3 is a conspicuous erosional contact with sediments belonging to Unit 4 . In several localities Unit 3 is directly overlain by the modern soil. Like the sediments of Unit 2, those of Unit 3 are cut off by two major paleo-gullies. In the northern part Unit 3 reaches a thickness of $0.6 \mathrm{~m}$, and it has the same thickness in the southern part of the area except for between L5 and L13, where the thickness is $2.0 \mathrm{~m}$. The sediments of Unit 3 strongly resemble these of Unit 2 . They are relatively finegrained and well-sorted, often dull yellow-orange sands. In shell beds, the sediments are on average coarser. The top of Unit 3 consists of well-sorted, fine-grained, dull yelloworange sands that are very poor in or devoid of fossils, except for scattered fish bones, and abundant bioturbation in the northern part.

Overall, Unit 3 occurs more patchily than Unit 2 and the outcrops north of the major paleo-gully and south of it have somewhat different characteristics. As mentioned and as supported by differences in shell bed composition, they may represent two separate transgressions. Shell beds are 
rarer in Unit 3 than in Units 1 and 2, however, sediments of Unit 3 in localities L1 and L2 contain many dispersed shells in addition to a few thick shell beds that contain abundant material of a relatively small Melanoides cf. turritispiralike morphotype (Fig. 6s) and a somewhat less abundant $M$. cf. pupiformis (Fig. 6t). In contrast, Bellamya and Lanistes are more frequent in the northern deposits of Unit 3, where Melanoides is rare. The $M$. cf. turritispira morphotype that dominates the southern deposits of Unit 3 is very similar to the one in Unit 2. No conspicuous morphological features have been observed that allow discerning the mollusk communities from Unit 2 and 3 based on intrinsic faunistic properties, though material of Unit 2 is generally better preserved. This is probably the reason why the fragile heterobranch gastropods of Unit 2 are lacking from Unit 3.

\subsubsection{Unit 4}

The age of deposits belonging to Unit 4 has not been established via absolute dating as for Units 1 to 3, but these sediments were deposited after deposition of Unit 3 and presumably before the Shire River was fully installed as outflow of Lake Malawi 5.5-5.0 ka BP (Ricketts and Johnson, 1996). The lower boundary of Unit 4 consists of erosional unconformities with sediments belonging to Units 1 to 3 . In profiles L3, L5, and L8A the direct erosional contact between Units 3 and 4 has been observed, but in other profiles this contact is more difficult to pinpoint. Unit 4 is overlain by the modern soil. Unit 4 ranges in thickness from several decimeters (L8A, L3) up to more than $2.5 \mathrm{~m}$ (L11, L12). Unit 4 consists of coarse-grained and poorly-sorted, dull yellow-orange/dull yellow-brown sands (sometimes including fine gravel) that rarely contain fossil material. As mentioned, the limited fossil finds have not been dated (and actually may represent reworked material). Unit 4 sediments show a compact sedimentation with only minor changes in grain sizes related to weak fining or coarsening up cycles. These sands have been deposited in higher energy environments than the other units of the Chipalamawamba Beds as is evidenced by regular oblique bedding and foresets (Fig. 2h).

Most sediments we studied of this unit were deposited in the main paleo-gully, which occurs between profiles L6A and L7A but extends beyond L7A up to L8A, is several hundreds of meters wide (in total perhaps up to $500 \mathrm{~m}$ ) and literally divides the fossil-bearing Units 1 to 3 on the western shore into a northern (north of L7A) and a southern (south of L6A) area. The second paleo-gully between L3 and L5, which also was filled up by sediments of Unit 4, is smaller (60-130 m wide) and separates the southern area into two subareas (L3 \& 4 vs. L1, 2, 5, 6 and 13). The first bed below the modern soil in profile L9A is perhaps attributable to Unit 4 too. No fossils have been obtained from deposits of Unit 4, except for a single and potentially reworked shell fragment and a few fishbone fragments.

\section{Discussion}

\subsection{Paleoenvironmental context}

Units 1 to 3 of the Chipalamawamba Beds consist predominantly of lake beds. The characteristics of the fossil assemblages (Table 2), the sedimentological properties of the beds and their broad geographical extent all suggest these units have been deposited mainly in shallow lacustrine conditions. Paludal circumstances may have prevailed occasionally, as is currently the case at the southern tip of Lake Malawi and at the margins of Lake Malombe. Deposition in paludal circumstances, evidenced by root casts, differences in the mollusk fauna and in some cases by the presence of a finer fraction in the sediments, remained geographically localized and restricted in time. The three lower units of the Chipalamawamba Beds hence represent three major phases of high stand of Lake Malawi, separated from one another by regressive phases, during which erosion of previously deposited lake sediments occurred. Within units, minor diastems (including intermediate erosional events) have been recognized also. The fourth and uppermost unit represents a different, higher energy environment. Its deposition took place shortly after that of Unit 3 and coincides with the development of the Shire River as the outlet of Lake Malawi. During this period, some existing paleo-river gullies that originated in the introductory phase of Unit 4, perhaps with precursors from the regressive phase between Units 2 and 3, filled with sediment as the Shire River formed its main riverbed and other deltaic paleo-gullies became defunct. This could have occurred very quickly from the moment throughflow diminished in the defunct paleo-gullies as the channel now known as the Shire River increased its discharge and cut its course through the lacustrine deposits. When the Shire River cut sufficiently deep for floods outside the riverbed to have become rare, the modern soil started developing on top of the Chipalamawamba sediments in the river banks. For reference, during our 2010 field campaign the bottom of the Shire River in the centre of the channel was $\sim 10 \mathrm{~m}$ below the water level and traces of the annual high water stands from the last decades were detected in sediments up to $\sim 1 \mathrm{~m}$ above the water level, but not higher. As mentioned, the current water level was $\sim 473-474$ ma.s.l., which corresponds well with previous measurements (Bootsma and Hecky, 2003).

The rate of sedimentation appears generally to have been high for the Chipalamawamba Beds. Sediments of Unit 2, for example, have typically been deposited very rapidly with intermediate diastems, e.g., all Unit 2 sediments in profile L7B $(\sim 1.0 \mathrm{~m})$ have been deposited in roughly $200 \mathrm{yr}$ between $\sim 7.6-7.4 \mathrm{cal} \mathrm{kaBP}$, whereas the $1.3 \mathrm{~m}$ of sediments in L4 appears to have been deposited in $500 \mathrm{yr}(\sim 7.5-$ 7.0 cal ka BP). About $1.3 \mathrm{~m}$ of Unit 2 in profile L8B was deposited in $150 \mathrm{yr}$ between 6.9-6.7 ka BP. Assuming constant sedimentation, this suggests deposition rates of $\sim 0.50$, 0.26 and $0.87 \mathrm{~m}$ per century, respectively. In Unit $1,1.1 \mathrm{~m}$ 
of sediments was deposited in L8B and L9A over $500 \mathrm{yr}$ ( $\sim 10.6-10.1 \mathrm{cal} \mathrm{ka} \mathrm{BP})$, suggesting $\sim 0.22 \mathrm{~m}$ per century under the same assumption. Sedimentation rates are hard to estimate for Unit 3, because of more limited age control and the possibility that these sediments reflect not one but two high stand phases. Rapid sedimentation is also suspected in Unit 4. The high energy environments in which deposition occurred and the narrow time window in between deposition of Unit 3 and the moment the Shire River became fully operational hint towards rates potentially even higher than the maximal estimates for Unit 2. Apart from the rapid deposition of units, the spread in radiocarbon dates indicates that individual shell beds were deposited quickly too. The oldest shell bed in Unit 1 has been dated to $9550 \pm 50$ and $9580 \pm 50{ }^{14} \mathrm{C}$ yr; another shell bed from Unit 2 was dated to $6200 \pm 40,6200 \pm 40$, and elsewhere to $6185 \pm 35{ }^{14} \mathrm{C} \mathrm{yr}$; laterally equivalent shell bed extensions in the south were dated to $6040 \pm 35$ and $6050 \pm 35{ }^{14} \mathrm{C}$ yr. Dating information hence strongly suggests individual shell beds to have been deposited over periods as short as a few decades.

Unit 1 was predominantly deposited in shallow lacustrine conditions ( 0 to $3 \mathrm{~m}$ of depth), with relatively strong wave action. Apart from the poorly sorted sediments, which contain a very coarse sand fraction, shell bed taphonomy supports this suggestion. Shells are abundant, but are regularly fragmented or broken, and some post-mortem transportation may have occurred. The top shell bed in this unit is a good example of this; it contains mainly rolled hinge fragments of bivalves and columellar fragments of gastropods. That Unit 1 only occurs in the northern deposits of the Chipalamawamba Beds could be explained in two ways. First, the earliest Holocene transgressive phase may have been less extensive than the later ones. Taking into account the bathymetry of Lake Malawi (Scholz and Rosendahl, 1988), the more extensive a transgressive phase, the farther south deposits would extend. As such, sediments deposited during less extensive high stands may only be recognizable in the north. This argument based on bathymetry also implies that erosion would be strongest in the south, as deposits in the south would generally surface earlier and longer than deposits in the north. The second explanation is that Unit 1 was also deposited farther south, but that southern deposits were eroded by the main paleo-gully. However, this last scenario cannot account for the absence of Unit 1 in deposits south of the main paleogully, and both explanations may have contributed to the present observations.

Unit 2 contains a larger fraction of fine sediments in the north, and towards the south, coarser grained and poorly sorted sediments become more abundant. In general, we observed that sediments lower in Unit 2 are generally coarser and less well-sorted than higher ones, and shell beds are deposited in relatively coarse sand. Even those shell beds sandwiched between finer-grained sediments normally contain coarser-grained sands. In layers of finer-grained sediments, dispersed shells regularly occur and the few shell beds that are deposited in fine-grained material do not show compositional differences from shell beds deposited in coarsergrained sediments. However, in contrast to the high energy shell accumulations preserved in Unit 1, those associated with coarse and relatively poorly sorted sediments in Unit 2 contain shells that are very well preserved. Bivalve specimens often display umbonal sculpture, the early teleoconchs of gastropods are usually intact and a rich community of heterobranch gastropods with fragile shells is present. This suggests that conditions during the lifetime of these animals and at the time of burial were calm enough to prevent shell abrasion and corrosion, and that burial occurred with sufficient rapidity to prevent abrasion in post-mortem transport. Whereas deposition may have taken place in rather shallow waters $(\sim 0-3 \mathrm{~m})$, many of the shells in Unit 2 probably belonged to animals that lived well below the surf zone, i.e., in waters of $\sim 3-5 \mathrm{~m}$, potentially deeper. Personal observations on living adult mollusks from shallower waters suggest that abrasion and corrosion of the teleoconch or the umbonal sculpture would have been unavoidable in shallow habitats. The diverse heterobranch assemblage, moreover, suggests the presence of abundant macrophytes near the site of deposition.

The sediments of Unit 3 document the last major high stand of the lake and are very similar to those of Unit 2, however on average, they are darker in color. The erosional unconformity between Units 2 and 3 is more difficult to discern than the one between Units 1 and 2, probably because the hiatus was much shorter ( $\sim 600 \mathrm{yr}$ compared to $\sim 2000 \mathrm{yr}$ ). Most deposits consist predominantly of fine-grained sands, but as in Unit 2 the sediments in shell beds are usually coarser than those in beds without shells. Outside the area between $\mathrm{L} 1$ and L2, however, shell beds are very rare in Unit 3. The fact that deposits of Unit 3 are scattered is probably due to erosion caused by the developing outflow shortly after the sediments were laid down. This erosion was probably patchy and rather widespread.

Unit 4 contains strata from the latest phase in the deposition of the Chipalamawamba Beds, and likely accumulated when the Shire River became functional. Sediments of Unit 4 have not been dated, but their stratigraphical position in combination with current estimates on the origin of the Shire River would imply Unit 4 was deposited rapidly. Also the sedimentological properties of deposits belonging to Unit 4 and their bearing on the depositional environments support fast deposition. Sediments of Unit 4 represent true riverine deposits that were formed when high lake levels of Lake Malawi resulted in substantial water discharge in the south. Coarse-grained sediments were deposited where previous river branches and paleo-gullies created accommodation space. As mentioned, these gullies filled up fast, potentially aided by decreasing discharge (and currents) via these channels when the channel now known as the Shire River expanded and increased its capacity to become the single outflow of Lake Malawi. While some gullies were filled with 
the coarse sediments belonging to Unit 4, the overall balance during this phase was perhaps more towards the side of erosion, and substantial parts of the older units of the Chipalamawamba Beds were eroded just before and during the period in which Unit 4 was deposited.

\subsection{Current erosion of the Chipalamawamba Beds}

Some outcrops of the Chipalamawamba Beds underwent a substantial amount of change between our fieldwork in 2008 and 2010 (compare e.g., Fig. 2a and b). Besides erosion at the water level by the Shire River, the increasing human population causes considerable additional erosion. People frequent the waterside for multiple basic needs. Moreover, fishermen are known to have engaged in digging out complete shell beds at or just below the waterline because towing over these fossil shell beds causes substantial damage to their fishing nets. This, in combination with the fact that most beds are strongly lenticular can result in future changes in the individual thickness of sediment layers and in the presence of fossil-bearing outcrops.

\subsection{Paleolimnological inferences on lake levels}

Hypotheses on late Quaternary lake levels of Lake Malawi are widely discussed in scientific literature, partly because the timing of its low and high stands appears out of phase with those from African lakes farther north (e.g., Finney et al., 1996; Gasse, 2000; Johnson et al., 2002; Filippi and Talbot, 2005) and secondly because the climatic history of the basin during the Holocene, particularly in the early Holocene, has not been resolved (Castañeda et al., 2007). For example, low lake levels $(100-150 \mathrm{~m}$ below present levels) were suggested for Lake Malawi during the early Holocene (10.0-6.0 ka BP) based on geochemical data from core sediments, diatom communities (Finney and Johnson, 1991; Finney et al., 1996), and from seismic features (Scholz and Finney, 1994). Similarly, vegetation records suggest that conditions were generally more arid $11.6-7.7 \mathrm{ka} \mathrm{BP}$ than at present (Meadows, 1984; DeBusk, 1998; Castañeda et al., 2007, 2009). Geochemical analyses of endogenic calcite suggest drying events between 9.0 and $8.5 \mathrm{kaBP}$, between 8.5 and $7.5 \mathrm{kaBP}$ and between 7.2 and $6.5 \mathrm{kaBP}$ (Ricketts and Johnson, 1996). Analyses of organic matter in sediment cores provides evidence for a much shorter duration $(\sim 2 \mathrm{ka})$ of the terminal Pleistocene-early Holocene low stand, with rising water levels $\sim 10.5$ to $10.0 \mathrm{kaBP}$, resulting in high lake levels $\sim 8.0 \mathrm{kaBP}$ (Filippi and Talbot, 2005). The scenario of high lake levels in the early and middle Holocene is generally supported by records of periphytic diatoms (Johnson et al., 2002). Records of planktonic diatoms support high or intermediate levels during much of the early Holocene, with short-lived regressions at 10.6 and $8.5-8.2 \mathrm{ka} \mathrm{BP}$ and a somewhat remarkable transgression 7.5-6.6 ka BP (Gasse et al., 2002). Finally, it is puzzling that several proxies from Lake
Malawi suggest low lake levels and aridity when the nearby Lake Rukwa experienced humid conditions from 12.1 to 5.5 ka BP (Haberyan, 1987; Vincens et al., 2005), with paleoshorelines during that interval at least temporarily reaching levels $\sim 200 \mathrm{~m}$ above the present day lake level (Delvaux et al., 1998). Also Lake Massoko, a volcanic crater lake in the Rungwe Highlands, experienced relatively wet conditions in this period (Barker et al., 2003).

After 6.0 ka BP lake levels in the Malawi Basin would have remained high and more stable than between 10.0 and 6.0 ka BP (Finney and Johnson, 1991; Finney et al., 1996; Ricketts and Johnson, 1996; Castañeda et al., 2007), with the onset of an open-basin regime when the Shire River became functional about 5.5-5.0 ka BP (Ricketts and Johnson, 1996). Indeed, productivity in the lake appears to have been enhanced because of stronger winds and/or wetter climatic conditions (Johnson et al., 2002). Similarly, terrestrial vegetation records suggest wetter conditions and decreased seasonality from $\sim 7.0$ until $\sim 2.5 \mathrm{ka}$ BP (Meadows, 1984; Debusk, 1998; Castañeda et al., 2009). The timing of the highest contribution of $\mathrm{C}_{3}$ vegetation (4.9 ka BP; Castañeda et al., 2007, 2009) appears to coincide roughly with the end of endorheic conditions. After $2.5 \mathrm{ka} \mathrm{BP}$, the vegetation indicates increasingly drier conditions again (Castañeda et al., 2009) and brief low stands have been reported for this period (Owen et al., 1990; Finney and Johnson, 1991). Planktonic diatoms, however, hint to generally lower lake levels over the last $4 \mathrm{ka} \mathrm{BP}$ than in the early Holocene (Gasse et al., 2002). Aridification would have started already from $5.5 \mathrm{ka} \mathrm{BP}$ in the Rukwa Basin (Vincens et al., 2005) and from $\sim 4.5 \mathrm{ka} \mathrm{BP}$ for Lake Massoko (Barker et al., 2003).

Our work in the Chipalamawamba Beds provides strong evidence for three periods of high lake levels in the early and middle Holocene. Contrasting the above mentioned sources, we rely solely on our age model, not on the interpretation of lake-level proxies. A first transgressive phase occurred 10.6-9.7 ka BP, a second one with more or less continuously high lake levels 7.6-6.5 ka BP and a third one 5.9$5.3 \mathrm{ka} \mathrm{BP}$. These data corroborate the $9.0-8.5 \mathrm{ka} \mathrm{BP}$ and the 8.5-7.5 ka BP drying events of Ricketts and Johnson (1996) as well as their estimate for the onset of open-basin conditions $(\sim 5.5-5.0 \mathrm{ka} \mathrm{BP})$. However, our data are in conflict with the 7.2-6.5 ka BP drying event of Ricketts and Johnson (1996), because a substantial part of the widespread deposits of Unit 2 were deposited during this period. Our data correspond well to the wet periods 7.5 and $5.3 \mathrm{ka} \mathrm{BP}$ and the aridity $\sim 8.2$ and $6.4 \mathrm{ka} \mathrm{BP}$ reported by Barker et al. (2007), except for their claim of aridity at $10.0 \mathrm{ka}$ BP. Findings from the Chipalamawamba Beds are also in correspondence with the regressions between $8.5-8.2 \mathrm{ka} \mathrm{BP}$ and the transgression between 7.5-6.6 ka BP reported by Gasse et al. (2002) based on planktonic diatoms, but they contradict these authors' short-lived regression at $10.6 \mathrm{ka} \mathrm{BP}$. Note that the periods indicated for high lake level phases above give conservative estimates for the end of high-water phases. High lake levels 
may have prevailed for quite a bit longer, and significant amounts of the upper lake sediments deposited during high water stands may have been eroded during subsequent erosional phases. Therefore, we cannot contradict that lake levels were high $9.0 \mathrm{ka} \mathrm{BP}$ (Barker et al., 2007) or $8.0 \mathrm{ka} \mathrm{BP}$ (Filippi and Talbot, 2005), even though this would imply that all sediments deposited after $9.7 \mathrm{ka} \mathrm{BP}$ would have been eroded in intermittent erosional phases or in the period between 8.0 and $7.6 \mathrm{ka} \mathrm{BP}$. The magnitude of lake level drops in between high-water phases remains speculative. Lake Malawi's water budget over $25 \mathrm{yr}(1954-1980)$ indicated that $\sim 60 \%$ of the water input derives from rainfall directly on the lake's surface and that $\sim 82 \%$ of the water leaving the lake evaporates from that same surface (Owen et al., 1990). Lake Malawi water levels are hence very susceptible to climatic changes, as was documented from recently obtained sediment cores (Scholz et al., 2007; Cohen et al., 2007). However, drops in lake level over the Holocene were presumably more moderate than the one during the Last Glacial Maximum when lake levels were $\sim 75-100 \mathrm{~m}$ below the current level (Konecky et al., 2011), which is corroborated by shoreline elevation constraints in core sediments (Cohen et al., 2007). Hence, a reasonable estimate for lake level drops during the early Holocene low stands would be on the order of ten to several tens of meters. In any case, the Chipalamawamba Beds clearly indicate that, at least periodically and regularly, Lake Malawi attained high lake levels in the early and middle Holocene, i.e., up to $5 \mathrm{~m}$ higher than at present. Although our data do not provide information on the magnitude of lake level drops during periods of low stands, they provide unambiguous evidence for oscillating lake levels and contrast with previous hypotheses of rather continuous high (Johnson et al., 2002) or low lake level phases (Finney and Johnson, 1991; Finney et al., 1996).

\subsection{Paleobiological relevance}

Mollusk assemblages are abundant in the Chipalamawamba Beds and material is in general very well preserved and can be retrieved relatively easily from the matrix. As mentioned above, time averaging in shell beds appears to be limited and fossil assemblages probably reflect living populations to a great extent, which facilitates paleoecological and evolutionary studies. Moreover, considerable morphological changes have occurred in the mollusk communities since deposition of the early Holocene fossil beds (e.g., changes in ornamentation in Melanoides, see Fig. 6; Van Bocxlaer and Schultheiß, 2010), and lineage splitting has putatively taken place (Van Bocxlaer, 2005). Indeed, diversification is ongoing in some of the taxa concerned, e.g., Lanistes and Bellamya (Schultheiß et al., 2009, 2011), and indications exist that explosive speciation occurred in some of the monophyletic, endemic mollusk clades of Lake Malawi (i.e., several more or less simultaneous lineage splits occur over a short period, coinciding with morphological differentiation, so that the phylogenetic relationships of the descendants are represented by a hard polytomy). These clades were sampled in the fossil beds. Therefore, the Chipalamawamba Beds offer a unique opportunity to complement neontological studies on the extant fauna (e.g., Genner et al., 2007; Schultheiß et al., 2009, 2011) with paleobiological studies of morphological evolution, diversification and divergence in fossil "populations" over time. Such complementary work is rarely possible for modern organismal radiations and it is particularly relevant in cases where morphological traits observed on the fossil material can be unambiguously related to the anatomical and life-history traits that supposedly led to the divergence of the modern taxa. Our stratigraphic and paleoenvironmental studies on the Chipalamawamba Beds moreover reveal a remarkable potential for high resolution paleontological time series analyses (100s to a few 1000s of years between subsequent beds; Table 1). These efforts may allow a narrowing of the "epistemological gap" between neontological and paleontological approaches to the study of organismal evolution (e.g., Kemp, 1999; Reznick and Ricklefs, 2009).

Acknowledgements. We thank chiefs Gundaphiri (Chipalamawamba) and Kwitambo-Dimba (Kwitambo) for allowing us to study the sediments and shell beds in their villages; we also thank chief Chowe (Kazembe) for allowing us to explore the outcrops near his village. We acknowledge the Cultural and Museum Centre Karonga for structural support and in particular Friedemann Schrenk, Harisson Simfukwe and Joseph Tembo for their assistance. More help in the field came from William, Daudi, Daud and Mike. Constructive suggestions on previous drafts of this paper were kindly provided by Frank H. Brown, Thomas C. Johnson, Jocelyn Sessa, Gene Hunt and 2 anonymous referees. We also thank Christian Albrecht for editing this paper. Financial support was provided by the Leopold III-fund, the Flanders Research Foundation and the Faculty of Sciences of Ghent University to BVB and JV. More support was provided by a Fellowship of the Belgian American Educational Foundation and a Peter-Buck Fellowship of the Smithsonian Institution to BVB.

Edited by: C. Albrecht

\section{References}

Barker, P., Williamson, D., Gasse, F., and Gibert, E.: Climatic and volcanic forcing revealed in a 50,000-year diatom record from Lake Massoko, Tanzania, Quaternary Res., 60, 368-376, 2003.

Barker, P., Leng, M. J., Gasse, F., and Huang, Y.: Century-tomillennial scale climatic variability in Lake Malawi revealed by isotope records, Earth Planet. Sc. Lett., 261, 93-103, 2007.

Barry, S. L.: Stratigraphic Correlation and High-Resolution Geochronology of Varved Sediments from Lake Malawi, East Africa, M.S. thesis, University of Minnesota, Duluth, 2001.

Barry, S. L., Filippi, M. L., Talbot, M. R., and Johnson, T. C.: A 20,000 yr sedimentological record from Lake Malawi, East Africa: the Late Pleistocene/Holocene transition in the southern tropics, in: The East African Great Lakes: Limnology, Palaeocli- 
matology and Biodiversity, edited by: Odada, E. O. and Olago, D. O., Kluwer Academic Publishers, Dordrecht, 369-392, 2002.

Bootsma, H. A. and Hecky, R. E.: Conservation of the African Great Lakes: A limnological perspective, Conserv. Biol., 7, 644-656, 1993.

Bootsma, H. A. and Hecky, R. E.: A comparative introduction to the biology and limnology of the African Great Lakes, J. Great Lakes Res., 29 (Supplement 2), 3-18, 2003.

Brown, D. S.: Freshwater snails of Africa and their medical importance, Taylor and Francis, London, 609pp., 1994.

Brown, E. T., Johnson, T. C., Scholz, C. A., Cohen, A. S., and King, J. W.: Abrupt change in tropical African climate linked to the bipolar seesaw over the past 55,000 years, Geophys. Res. Lett., 34, L20702, doi:10.1029/2007GL031240, 2007.

Castañeda, I. S., Werne, J. P., and Johnson, T. C.: Wet and arid phases in the southern African tropics since the Last Glacial Maximum, Geology, 35, 823-826, 2007.

Castañeda, I. S., Werne, J. P., Johnson, T. C., and Filley, T. R.: Late Quaternary vegetation history of southeast Africa: the molecular isotopic record from Lake Malawi, Palaeogeogr. Palaeocl., 275, 100-112, 2009.

Cohen, A. S., Stone, J. R., Beuning, K. R. M., Park, L. E., Reinthal, P. N., Dettman, D., Scholz, C. A., Johnson, T. C., King, J. W., Talbot, M. R., Brown, E. T., and Ivory, S. J.: Ecological consequences of early Late Pleistocene megadroughts in tropical Africa, P. Natl. Acad. Sci. USA, 42, 16422-16427, 2007.

Crossley, R. and Davison-Hirschmann, S.: High levels of Lake Malawi during the Late Quaternary, in: Palaeoecology of Africa, edited by: Coetzee, J. A. and Van Zinderen, Bakker, E. M., A. A. Balkema, Rotterdam, 15, 109-115, 1982.

DeBusk, G. H.: A 37,500-year pollen record from Lake Malawi and implications for the biogeography of afromontane forests, J. Biogeogr., 25, 479-500, 1998.

Delvaux, D., Kervyn, F., Vittori, E., Kajara, R. S. A., and Kilembe, E.: Late Quaternary tectonic activity and lake level change in the Rukwa Rift basin, Journal of African Earth Sciences, 26, 397421, 1998

Gasse, F.: Hydrological changes in the African tropics since the Last Glacial Maximum, Quaternary Sci. Rev., 19, 189-211, 2000.

Gasse, F., Barker, P., and Johnson, T.: A 24,600 yr diatom record from the Northern Basin of Lake Malawi, in: The East African Great Lakes: Limnology, Palaeolimnology and Biodiversity, Advances in Global Change Research, edited by: Odada, E. O. and Olago, D. O., Kluwer Academic Publishers, Dordrecht, 393-414, 2002.

Genner, M. J., Todd, J. A., Michel, E., Erpenbeck, D., Jimoh, A., Joyce, D. A., Piechocki, A., and Pointier, J.-P.: Amassing diversity in an ancient lake: evolution of a morphologically diverse parthenogenetic gastropod assemblage in Lake Malawi, Mol. Ecol., 16, 517-530, 2007.

Gorthner, A.: Grenzen paläontologischer Systematik und Stratigraphie in lakustrischen Biotopen am Beispiel rezenter und fossiler Mollusken des Malawisees, Neues Jahrb. Geol. P.-M., 8, 487$500,1994$.

Haberyan, K. A.: Fossil diatoms and the paleolimnology of Lake Rukwa, Tanzania, Freshwater Biol., 17, 429-436, 1987.

Fairbanks, R. G., Mortlock, R. A., Chiu, T.-C., Cao, L., Kaplan, A., Guilderson, T. P., Fairbanks, T. W., and Bloom, A. L.: Marine radiocarbon calibration curve spanning 0 to 50,000 years
B.P. based on paired ${ }^{230} \mathrm{Th} /{ }^{234} \mathrm{U} /{ }^{238} \mathrm{U}$ and ${ }^{14} \mathrm{C}$ dates on pristine corals, Quaternary Sci. Rev., 24, 1781-1796, 2005.

Finney, B. P. and Johnson, T. C.: Sedimentation in Lake Malawi (East Africa) during the past 10,000 years: a continuous paleoclimatic record from the southern tropic, Palaeogeogr. Palaeocl., 85, 351-366, 1991.

Finney, B. P., Scholz, C. A., Johnson, T. C., and Trumbore, S.: Late Quaternary lake-level changes of Lake Malawi, in: The limnology, climatology and paleoclimatology of the East African Lakes, edited by: Johnson, T. C. and Odada, E. O., Gordon and Breach, Amsterdam, 495-508, 1996.

Filippi, M. L. and Talbot, M. R.: The palaeoclimatology of northern Lake Malawi over the last 25 ka based upon the elemental and stable isotopic composition of sedimentary organic matter, Quaternary Sci. Rev., 24, 1303-1328, 2005.

Johnson, T. C., Brown, E. T., McManus, J., Barry, S., Barker, P., and Gasse, F.: A high-resolution paleoclimate record spanning the past 25,000 years in Southern East Africa, Science, 296, 113 132, 2002.

Kemp, T. S.: Fossils and Evolution, Oxford University Press, Oxford, 284pp., 1999.

Konecky, B. L., Russell, J. M., Johnson, T. C., Brown, E. T., Berke, M. A., Werne, J. P., and Huang, Y.: Atmospheric circulation patterns during late Pleistocene climate changes at Lake Malawi, Africa, Earth Planet. Sc. Lett., 312, 318-326, 2011.

Krynine, P. D.: The megascopic study and field classification of sedimentary rocks, J. Geol., 56, 130-165, 1948.

Mandahl-Barth, G.: The freshwater Mollusca of Lake Malawi, Revue de Zoologie et de Botanique africaines, 86, 257-289, 1972.

Meadows, M. E.: Late Quaternary vegetation history of the Nyika Plateau, Malawi, J. Biogeogr., 11, 209-222, 1984.

Oyama, M. and Takehara, H.: Revised Standard Soil Color Charts, Ministry of Agriculture and Forestry, Japan, Tokyo, 43 pp., 1967.

Owen, R. B., Crossley, R., Johnson, T. C., Tweddle, D., Kornfield, I., Davison, S., Eccles, D. H., and Engstrom, D. E.: Major low levels of Lake Malawi and their implications for speciation rates in cichlid fishes, P. Roy. Soc. B.-Biol. Sci., 240, 519-553, 1990.

Ricketts, R. D. and Johnson, T. C.: Early Holocene changes in lake level and productivity in Lake Malawi as interpreted from oxygen and carbon isotopic measurements of authigenic carbonates, in: The limnology, climatology and paleoclimatology of the East African Lakes, edited by: Johnson, T. C. and Odada, E. O., Gordon and Breach, Amsterdam, 475-493, 1996.

Reznick, D. N. and Ricklefs, R. E.: Darwin's bridge between microevolution and macroevolution, Nature, 457, 837-842, 2009.

Scholz, C. A. and Finney, B. P.: Late Quaternary sequence stratigraphy of Lake Malawi (Nyasa), Africa, Sedimentology, 41, 163179, 1994.

Scholz, C. A. and Rosendahl, B. R.: Low lake stands in lakes Malawi and Tanganyika, East Africa, delineated with multifold seismic data, Science, 240, 1645-1648, 1988.

Scholz, C. A., Johnson, T. C., Cohen, A. S., King, J. W., Peck, J. A., Overpeck, J. T., Talbot, M. R., Brown, E. T., Kalindekafe, L. Amoako, P. Y. O., Lyons, R. P., Shanahan, T. M., Castañeda, I. S., Heil, C. W., Forman, S. L., McHargue, L. R., Beuning, K. R., Gomez, J., and Pierson, J.: East African megadroughts between 135 and 75 thousand years ago and bearing on early-modern human origins, P. Natl. Acad. Sci. USA, 42, 16416-16421, 2007. 
Schultheiß, R., Van Bocxlaer, B., Wilke, T., and Albrecht, C.: Old fossils-young species: evolutionary history of an endemic gastropod assemblage in Lake Malawi, P. Roy. Soc. B.-Biol. Sci., 276, 2837-2846, 2009.

Schultheiß, R., Wilke, T., Jørgensen, A., and Albrecht, C.: The birth of an endemic species flock: demographic history of the Bellamya group (Gastropoda, Viviparidae) in Lake Malawi, Biol. J. Linn. Soc., 102, 130-143, 2011.

Van Bocxlaer, B.: Changes in the malacofauna of Lake Malawi since mid-Holocene times, Geol. Belg., 8, p. 124, 2005.

Van Bocxlaer, B. and Schultheiß, R.: Comparison of morphometric techniques for shapes with few homologous landmarks based on machine-learning approaches to biological discrimination, Paleobiology, 36, 497-515, 2010.
Vincens, A., Buchet, G., Williamson, D., and Taieb, M.: A 23,000 yr pollen record from Lake Rukwa ( $8^{\circ} \mathrm{S}, \mathrm{SW}$ Tanzania): New data on vegetation dynamics and climate in Central East Africa, Rev. Palaeobot. Palyno., 137, 147-162, 2005.

Zervas, D., Nichols, G. J., Hall, R., Smyth, H. R., Lüthje, C., and Murtagh, F.: Sedlog: A shareware program for drawing graphic logs and log data manipulation, Comput. Geosci.-UK, 35, 21512159, 2009. 